\title{
Nutrient Removal through Plant Components of Low Yielding Coconut Plantation
}

\author{
D. M. D. I. Wijebandara ${ }^{1}$, C. P. A. Kurudukubura ${ }^{2}$ and D. P. Panditharathna ${ }^{3}$ \\ Soils \& Plant Nutrition Division, Coconut Research Institute, Lunuwila 61150, Sri Lanka \\ ${ }^{\prime}$ Corresponding author: iraniew@gmail.com
}

\section{ABSTRACT}

The potential production of different lands varies depending on the quality of the land. The land suitability class $\mathrm{S}_{4}$; moderately suitable and $\mathrm{S}_{5}$; marginally suitable lands yielding 5,000 to 10,000 nuts $\mathrm{ha}^{-1} \mathrm{yr}^{-1}$ and 2,500 to 5,000 nuts $\mathrm{ha}^{-1} \mathrm{yr}^{-1}$ for coconut respectively are regarded as low potential productivity lands. These lands have limitations which are moderately severe and reduce the level of coconut productivity. Thus, these lands require inputs like fertilizer and agricultural practices like contour drains or terracing, husk pits, cover crops and mulch around the palms to break even cost and bring about profit to moderate level. Fertlizer application is one of the important inputs for such lands. The information on macro and micronutrient removal by Typica $x$ Typica (CRI 60 ) coconut palms and required fertilizer input to compensate the loss of nutrients in low potential productivity lands are not available. Therefore, the objective of this study was to estimate the macro and micronutrient removal by coconut palms in low yielding lands and to compare nutrient removal with fertilizer inputs and soil reserves.

Harvested nuts, fallen fronds and fallen inflorescences were collected monthly interval for three years from ten coconut palms of Typica $x$ Typica (CRI 60) grown on moderately suitable Boralu series soil (Red Yellow Podzolic). The macro and micronutrients in plant components and nutrient reserves in experimental site were determined. The results reavealed that the major nutrient removed by all plant parts were $164,53,37,22,19$ and $9.85 \mathrm{~kg}^{-1} \mathrm{ha}^{-1} \mathrm{yr}^{-1}$ for K, N, Na, Ca, $\mathrm{Mg}$ and $\mathrm{P}$ respectively. The amount of $\mathrm{N}, \mathrm{P}, \mathrm{K}, \mathrm{Ca}$ and $\mathrm{Mg}$ applied annually as fertilizers were 58 , 11.5, 125.9, 69.9 and $19 \mathrm{~kg}^{-1} \mathrm{ha}^{-1}$ respectively. Except $\mathrm{K}$ and $\mathrm{Mg}$, the other macronutrients, input by application of fertilizer slightly exceeds the nutrient removal. The $\mathrm{N}, \mathrm{P}, \mathrm{Ca}$ and $\mathrm{Mg}$ reserves of soil was high and would not deplete rapidly. The $\mathrm{K}$ input by application of $3.3 \mathrm{~kg}$ of APM fertilizer mixture was about $76.7 \%$ of the $\mathrm{K}$ removal. This leads to depletion of exchangeable $\mathrm{K}$ pool rapidly, if the harvested nuts and fallen plant components are all removed from the plantation. Hence, the depletion should be compensated for either by adding extra $80 \mathrm{~kg} \mathrm{ha}^{-1}$ of Muriate of Potash or recycling of fallen fronds and residues of the inflorescences or mulching the manure circle using fresh coconut husks or addition of organic manure. 
$\mathrm{ha}^{-1} \mathrm{yr}^{-1}$ for $\mathrm{Fe}, \mathrm{Mn}, \mathrm{Zn}, \mathrm{B}$ and $\mathrm{Cu}$ respectively. The reserves of available $\mathrm{Fe}, \mathrm{Mn}, \mathrm{Cu}$ and $\mathrm{Zn}$ in Boralu series soil was very high and the gap between the soil reserves and the plant removal rates were high. Hence, micronutrient containing fertilizers would not be required as the depletion of micronutrient reserves in soil would not occurre significantly.

Key words: coconut, nutrient removal, low yielding, soil reserves, fertilizer input

\section{INTRODUCTION}

Coconut palm regularly removes plant nutrients along with harvested nuts, fallen fronds and other parts of the inflorescences. Previous studies have shown that the harvested nuts, fronds and most of the other residues that are fallen from the palm, remove a considerable quantity of macro and micronutrients (Somasiri et al. 2003; Somasiri et al. 2001; Somasiri et al.; 2000, Jayasekara et al.; 1991, Ohler, 1984; Ouvrier and Ochs, 1980; Jeganathan et al. 1977). Such removals lead to gradual depletion of plant nutrients from coconut lands (Somasiri et al. 2001, 2003). Application of fertilizer containing $\mathrm{N}, \mathrm{P}, \mathrm{K}$ and $\mathrm{Mg}$ may compensate the aforementioned macro nutrient depletion. However, application of micronutrients to coconut palms is not currently practiced.

Nutrient removal studies would provide a basis for understanding the rate and amount of nutrient depletion from soil. The information on the nutrient depletion from those coconut eco-systems, which belong to different potential productivity categories, are useful in formulating fertilizer recommendations. The potential for coconut production of different lands varies depending on the quality of the land. The variation in climate, relief, soils, hydrology and vegetation influence the coconut productivity in varying degrees. Within a region of fairly uniform climate, relief and hydrology, soil is the main cause of differences in the productivity of coconut (Somasiri, et al. 1994).
In coconut land suitability classification, the land suitability class $S_{1}$; highly suitable and $\mathrm{S}_{2}$; suitable to highly suitable lands yielding more than 15,000 nuts $\mathrm{ha}^{-1} \mathrm{yr}^{-1}$ and 12,500 to 15,000 nuts $\mathrm{ha}^{-1} \mathrm{yr}^{-1}$ respectively, are regarded as high potential productivity lands. In those lands, there are no severe limitations to sustained coconut production. The $\mathrm{S}_{1}$ lands in some areas in Dry zone would experience moisture stress brief period of the year and $\mathrm{S}_{2}$ lands experience moisture stress during the dry period of the year. There are no significant moisture stress for coconut in these lands throughout the year. Therefore, under normal circumstances, strict moisture conservation practices may not be essential. Mulching and occasional weeding are the cultural practices that can be adopted (Somasiri, et al. 1994). High nut production in those coconut lands resulted in the removal of large quantity of soil nutrients and therefore fertilizer application should be adjusted to compensate for the loss. Somasiri et al., 2003 carried out a nutrient removal study using Typica $x$ Typica (CRI 60) coconut palms which are grown on high potential land (Madampe series soil). Results indicated that the amount of macronutrient removal through the plant components were higher than the input supply by one and half times of recommended dose of fertilizer comprising $1200 \mathrm{~g}$ of Urea, 1350 $\mathrm{g}$ of Eppawela Rock Phosphate (ERP), 2400 $\mathrm{g}$ of Muriate of Potash (MOP) with $1500 \mathrm{~g}$ of dolomite palm ${ }^{-1} \mathrm{yr}^{-1}$. This study further indicated that soil reserves depletion was very rapid due to higher production level of coconut palms and 
the depletion was compensated by application of one and half times of recommended dose of fertilizer and recycling of organic compounds of the coconut palm itself (Somasiri et al, 2003).

The land suitability class $\mathrm{S}_{4}$ moderately suitable and $\mathrm{S}_{5}$; marginally suitable lands yielding 5,000 to 10,000 nuts $\mathrm{ha}^{-1} \mathrm{yr}^{-1}$ and 2,500 to 5,000 nuts ha ${ }^{-1} \mathrm{yr}^{-1}$ respectively, are regarded as low potential productivity lands. These lands have limitations which are moderately severe for sustained coconut production. These limitations will reduce the coconut productivity level and thus these lands require adoption of good agricultural practices (contour drains or terracing, husk pits, cover crops, mulch around the palms) including fertilizers application to break even cost and bring about profit to moderate level. The depletion rate of soil nutrients in these coconut lands would be low due to low nut production. The information on amount of macro and micronutrient removal by Typica $x$ Typica (CRI 60) coconut palms and required fertilizer input to compensate the loss of nutrients in low potential lands are scanty. Therefore the objective of the study was to estimate the macro and micronutrient removal by Typica $x$ Typica (CRI 60) coconut palms in low potential coconut plantation and to compare nutrient removal with fertilizer inputs and soil reserves.

\section{MATERIALS AND METHODS}

Mature and fallen nuts, fronds and parts of the inflorescences were collected monthly for a period of three years from randomly selected ten Typica x Typica (CRI 60) coconut palms (25 years of old) from land suitability class $\mathrm{S}_{4}$; moderately suitable on Boralu series soil (Red Yellow Podzolic) at Bandirippuwa estate, Lunuwila. Each coconut palm was treated with $3.3 \mathrm{~kg}$ of recommended dose of fertilier comprising $800 \mathrm{~g}$ of Urea, $900 \mathrm{~g}$ of ERP, 1600 $\mathrm{g}$ of MOP and $1000 \mathrm{~g}$ of Dolomite once a year. Number of collected nuts (mature nuts and button nuts), fronds and different parts of the inflorescences were recorded. The collected nuts were partitioned into perianth, husks, shells, kernels and nut water, fronds into leaf blade, ekel and pithiole and inflorescences into spathes, spikelets, scars, dry spathe, female flowers and male flowers. The fresh and dry weight of each plant component of the main plant parts viz; leaf blade, ekel, pithiole, spathes, spikelets, scars, dry spathe, female flowers, male flowers, husks, shell, kernel and and the volume of the nut water were determined. Chemical analysis were performed on representative sub samples of each component at every month for three years. The samples of the aforementioned components except nut water and kernel were cleaned and dried at $70{ }^{\circ} \mathrm{C}$ for three days and crushed to powder form for chemical analysis. Nitrogen of each sample (including nut water and kernel) was determined by the Kjedhal method (Bremner and Mulvaney, 1982). Nut water samples were analysed for $\mathrm{N}$ after reducing the volume by evaporation. The $\mathrm{P}, \mathrm{K}, \mathrm{Ca}, \mathrm{Mg}, \mathrm{S}$, $\mathrm{Na}, \mathrm{Fe}, \mathrm{Mn}, \mathrm{Cu}$ and $\mathrm{Zn}$ were determined by digesting plant samples except nut water and kernel in $4: 1 \mathrm{HNO}_{3} / \mathrm{HClO}_{4}$ mixture (Kakulu and Jacob, 2006) followed by analysis using Auto Analyser 3 BRAN LUEBBE/Atomic Adsorption Spectrophotometer (GBC 904AA). Nut water samples were analysed for $\mathrm{P}, \mathrm{K}, \mathrm{Ca}, \mathrm{Mg}, \mathrm{S}, \mathrm{Na}$, $\mathrm{Fe}, \mathrm{Mn}, \mathrm{Cu}$ and $\mathrm{Zn}$ after evaporating to dryness followed by dry ashing at $450^{\circ} \mathrm{c}$. The kernel analysis were performed on solutions prepared after ashing at $450^{\circ} \mathrm{C}$. Boron was determined by colorimetry with azomethine - $\mathrm{H}$ reagent after ashing the plant material with $\mathrm{CaO}$ and dissoliving in dilute $\mathrm{H}_{2} \mathrm{SO}_{4}$. For determination of available nutrients in the soil, composite soil 
samples were collected from the manure circle of each palm and the center of the four coconut palms upto the depth of $0-15 \mathrm{~cm}$ and $15-100$ $\mathrm{cm}$ from the surface before application of fertilizer at once in every year for three years.

Air dried, $2 \mathrm{~mm}$ sieved soil samples were used for analysis. Total $\mathrm{N}$ of the soil samples was determined by the Kjeldhal digestion method (Bremner and Mulvaney, 1982). Available P content in the soil was determined by Olsen's bicarbonate method (Olsen et al. 1954), exchangeable bases by $1 \mathrm{M}$ ammonium acetate mehod (Thomas, 1982) and the available Fe, $\mathrm{Mn}, \mathrm{Cu}$ and $\mathrm{Zn}$ in soil by $0.005 \mathrm{M}$ DTPA-TEA extraction (Lindsay and Novell, 1978). Data analysis were done using MINITAB $15 \mathrm{soft}$ ware package.

\section{RESULTS AND DISCUSSION}

The average quantity of total dry matter produced by a hectare coconut plantation yielding 7,500 nuts during the 3 years period was $13,094 \mathrm{~kg}$ that comprised of $7,578 \mathrm{~kg}$ of nuts, $3,918 \mathrm{~kg}$ of fronds and $1,598 \mathrm{~kg}$ of inflorescences
(Table 1). Dry matter production in high yielding plantation was $28,899 \mathrm{~kg} \mathrm{ha}^{-1}$ compared with low yielding plantations (Somasiri et al. 2003). The nut weight contributes almost $58 \%$ of the total dry matter production of the coconut plantation whereas the weight of fronds contributes to $30 \%$ and weight of inflorescences contributes to $12 \%$. If the nuts and fronds are totally removed from the field, about $88 \%$ of the dry matter produced by the palms is taken away from the field along with the nutrients (Table 1). Similar trend was observed in composition of dry matter in high yielding plantations (Somasiri et al. 2003).

According to the Table 2, different parts of the nut removed different quantities of macronutrients. The nuts removed much larger quantities of $\mathrm{K}$ and $\mathrm{N}$ than $\mathrm{P}, \mathrm{Na}, \mathrm{Ca}$ and $\mathrm{Mg}$. The data showed that $98.9 \mathrm{~kg} \mathrm{ha}^{-1}$ of $\mathrm{K}$ was removed by the husk whereas only $24.3 \mathrm{~kg} \mathrm{ha}^{-1}$ of $\mathrm{K}$ was removed by all the other components of the nut. In contrast, $16.3 \mathrm{~kg} \mathrm{ha}^{-1}$ of $\mathrm{N}$ was removed by kernel whereas only $11.0 \mathrm{~kg} \mathrm{ha}^{-1}$ of $\mathrm{N}$ was removed by all the other parts of the nut.

Table 1: Dry matter production of different components removed by coconut palms yielding 7,500 nuts ha $^{-1}$ yr $^{-1}$

\begin{tabular}{|c|c|c|c|c|c|}
\hline Plant Component & $1^{\text {st }}$ Year & $2^{\text {nd }}$ Year & $3^{\text {rd }}$ year & Mean & Percentage of the total \\
\hline \multicolumn{6}{|c|}{$\left(\mathrm{kg} \mathrm{ha}^{-1}\right)$} \\
\hline Nut & 7,462 & 7,558 & 7,716 & 7,578 & 58 \\
\hline Fallen fronds & 3,847 & 3,881 & 4,025 & 3,918 & 30 \\
\hline Inflorocence & 1,623 & 1,269 & 1,902 & 1,598 & 12 \\
\hline Total & 12,932 & 12,708 & 13,643 & 13,094 & 100 \\
\hline
\end{tabular}


It is noteworthy that $80 \%$ of the total $\mathrm{K}$ in nuts was removed by husks. The kernel $\mathrm{N}$ contributed $60 \%$ to the total $\mathrm{N}$ removal from nut. The $\mathrm{K}$ removal by the nut water and shell were 5.29 and $8.7 \mathrm{~kg} \mathrm{ha}^{-1}$ respectively which are quite high compared to the other elements. The data showed that $3.07 \mathrm{~kg} \mathrm{ha}^{-1}$ of $\mathrm{P}$ was removed by the kernel whereas only $2.73 \mathrm{~kg} \mathrm{ha}^{-1}$ of $\mathrm{P}$ was removed by all the other components of the nut. The kernel removed higher quantities of the $\mathrm{P}$ than nut water, shell and husk. The 8.31 $\mathrm{kg}$ of $\mathrm{Na}, 2.7 \mathrm{~kg}$ of $\mathrm{Ca}$ and $2.57 \mathrm{~kg}$ of $\mathrm{Mg}$ was removed by husk whereas only $1.94 \mathrm{~kg}$ of $\mathrm{Na}$, $0.88 \mathrm{~kg}$ of $\mathrm{Ca}$ and $2.1 \mathrm{~kg}$ of $\mathrm{Mg}$ was removed by all the other components of the nut. Among all the macro nutrients removed from nuts, $\mathrm{Ca}$ was the lowest. Similar nutrient distribution in nuts were observed in high yielding plantations (Somasiri et al. 2000 and 2003).

The fronds removed larger quantities of $\mathrm{K}$ and $\mathrm{Na}$ than N, P, Ca and Mg (Table 3). The leaf blade removed a high propotion of $\mathrm{N}$ compared to the other parts of the frond. It is noteworthy that the petiole removes more $\mathrm{Na}$ than $\mathrm{K}$ and the total quantity of Na removed by fronds becomes second only to that of $\mathrm{K}$. The $\mathrm{Na}, \mathrm{K}, \mathrm{Ca}$ and $\mathrm{Mg}$ contents in the petiole were higher than that in the leaf blade and ekel. The ekel removed higher $\mathrm{K}$ than other nutrients whereas the Premoval is the lowest. Among all macronutrients removed from fronds, $\mathrm{P}$ was the lowest.

Table 2: Removed macronutrients from the field by nut yielding 7,500 nuts ha $\mathrm{hr}^{-1} \mathrm{yr}^{-1}$ differnt components of nuts

\begin{tabular}{lllllll}
\hline Components of the nut & $\mathbf{N}$ & $\mathbf{P}$ & $\mathbf{K}$ & $\mathbf{N a}$ & $\mathbf{C a}$ & $\mathbf{M g}$ \\
\hline & & \multicolumn{7}{c}{$\left(\mathrm{kg} \mathrm{ha}^{-1} \mathbf{~ v r}^{-1}\right)$} \\
Nut water & 0.11 & 0.15 & 5.29 & 1.02 & 0.33 & 0.14 \\
Shell & 1.17 & 0.32 & 8.7 & 0.62 & 0.19 & 0.21 \\
Kernal & 16.3 & 3.07 & 10.3 & 0.30 & 0.36 & 1.75 \\
Husk & 9.75 & 2.26 & 98.9 & 8.31 & 2.70 & 2.57 \\
\hline Total & 27.33 & 5.8 & 123.2 & 10.25 & 3.58 & 4.67 \\
\hline
\end{tabular}

Table 3: Macronutrient removed from the field by yielding 7,500 nuts $\mathrm{ha}^{-1} \mathrm{yr}^{-1}$ by differet components of fronds

\begin{tabular}{lllllll}
\hline Parts of the frond & $\mathbf{N}$ & $\mathbf{P}$ & $\mathbf{K}$ & $\mathbf{N a}$ & $\mathbf{C a}$ & $\mathbf{M g}$ \\
\hline & \multicolumn{7}{c}{$\left(\mathrm{kg} \mathrm{h}^{-1} \mathbf{~} \mathbf{~ r ~}^{-1}\right)$} \\
\hline Leaf blade & 14.56 & 1.23 & 9.52 & 2.0 & 5.63 & 1.64 \\
Petiole & 3.71 & 0.92 & 18.1 & 20.25 & 8.72 & 7.67 \\
Ekel & 1.65 & 0.48 & 3.22 & 0.72 & 2.24 & 1.32 \\
\hline Total & 19.9 & 2.63 & 30.8 & 22.9 & 16.5 & 10.6 \\
\hline
\end{tabular}


As shown in Table 4, inflorescences remove higher quantities of $\mathrm{K}$ and $\mathrm{N}$ compared to other nutrients. The $\mathrm{K}$ removed from inflorescences were the highest and $P$ removed were the lowest among all the macro nutrients analysed.

The total quantities of $\mathrm{N}, \mathrm{P}$ and $\mathrm{K}$ removed by fronds were much lower than that by nuts. In case of $\mathrm{N}$, the above difference was related to the weights of each component, as the $\mathrm{N}$ concentration in both components was $0.42 \%$ (not in given data). With $\mathrm{K}$, both lower weight and lower $\mathrm{K}$ concentration of the fronds $(0.78 \%$ in fronds and $1.01 \%$ in nuts - not in given data) accounted for the difference. However, the quantities of $\mathrm{Na}, \mathrm{Ca}, \mathrm{Mg}$ removed by fronds were quite high compared to those by nuts. It is important to note that the coconut husk produced in a year contain $98.9 \mathrm{~kg} \mathrm{ha}^{-1}$ (Table 2) which is $60 \%$ of the total $\mathrm{K}$ removal. The quantity of macronutrients removed through inflorescences were lower than quantity removed by nuts and fronds (Table 5). Higher amounts of nutrients from nuts, fronds and inflorescence were removed from higher yielding plantations compared to low yielding plantations (Somasiri et al. 2001 and 2003).

With regard to the total removal of macronutrients, $\mathrm{K}$ was the highest. The other macronutrient removal in decending order was $\mathrm{N}, \mathrm{Na}, \mathrm{Ca}, \mathrm{Mg}$ and $\mathrm{P}$ respectively. The analysis showed that $\mathrm{K}$ was the major plant nutrient contained in all plant parts and the total $\mathrm{K}$ removal was $164.2 \mathrm{~kg} \mathrm{ha}^{-1} \mathrm{yr}^{-1}$ which was 1.22 $\%$ of the total dry matter. The next highest removal was of $\mathrm{N}$ amounting to $53.3 \mathrm{~kg} \mathrm{ha}^{-1}$ $\mathrm{yr}^{-1}$ which was $0.40 \%$ of the total dry matter. Other macro nutrients removal were $\mathrm{Na}, \mathrm{Ca}$, $\mathrm{Mg}$ and $\mathrm{P}$ amounting to $0.28 \%, 0.16 \%, 0.14 \%$ and $0.07 \%$ of the total dry matter respectively. The $\mathrm{N}: \mathrm{K}$ ratio in the total plant parts was $1: 3.08$ wheras that in only nuts was $1: 4.51$. Other major nutrients such as $\mathrm{P}, \mathrm{Ca}$ and $\mathrm{Mg}$ were present in relatively low quantities, for example ratio of $\mathrm{P}: \mathrm{K}$ was $1: 16.7$ and that of $\mathrm{Mg}: \mathrm{K}$ was $1: 8.83$ (Table 5).

Table 4 : Macronutrients removed from the field by inflorescences

\begin{tabular}{lllllll}
\hline & $\mathbf{N}$ & $\mathbf{P}$ & $\mathbf{K}$ & $\mathbf{N a}$ & $\mathbf{C a}$ & $\mathbf{M g}$ \\
\hline Inflorescence & 6.08 & 1.42 & 10.2 & 4.01 & 1.85 & 3.38 \\
\hline
\end{tabular}

Table 5: Macronutrients removed from the field by nuts, fallen fronds and inflorescences of the palms yielding 7,500 nuts $\mathrm{ha}^{-1} \mathrm{yr}^{-1}$

\begin{tabular}{lllllll}
\hline Parts of the frond & $\mathbf{N}$ & $\mathbf{P}$ & $\mathbf{K}$ & $\mathbf{N a}$ & $\mathbf{C a}$ & $\mathbf{M g}$ \\
\hline & \multicolumn{5}{c}{$\left(\mathrm{kg} \mathrm{ha}^{-1} \mathbf{~ r r}^{-1}\right)$} \\
\hline Nuts & 27.3 & 5.80 & 123.2 & 10.25 & 3.58 & 4.67 \\
Fronds & 19.9 & 2.63 & 30.8 & 22.9 & 16.5 & 10.6 \\
Inflorescence & 6.08 & 1.42 & 10.2 & 4.01 & 1.85 & 3.38 \\
\hline Total & 53.3 & 9.85 & 164.2 & 37.16 & 21.9 & 18.6 \\
\hline
\end{tabular}


Table 6: Quantities of macronutrients (i) loss from the site via removal of plant components, (ii). As soil reserves in available form and (iii). Supplied by fertilizr inputs

\begin{tabular}{|c|c|c|c|c|c|}
\hline & $\mathbf{N}$ & $\mathbf{P}$ & $\mathbf{K}$ & $\mathrm{Ca}$ & Mg \\
\hline & \multicolumn{5}{|c|}{$\left(\mathrm{kg} \mathrm{ha}^{-1} \mathrm{yr}^{-1}\right)$} \\
\hline $\begin{array}{l}\text { (i). Nutrient removal by } \\
\text { nuts, fronds and } \\
\text { inflorescence of } \\
\text { coconut palm a }\end{array}$ & 53.3 & 9.85 & 164.2 & 21.9 & 18.6 \\
\hline $\begin{array}{l}\text { (ii). Soil nutrient content } \\
\text { (upto } 1 \mathrm{~m} \text { depth) }{ }^{\text {b }}\end{array}$ & $3726^{d}$ & $318^{e}$ & $570^{f}$ & $989^{f}$ & $235^{\mathrm{r}}$ \\
\hline $\begin{array}{l}\text { (iii). Nutrient supplied by } \\
\text { application of } 3.3 \mathrm{~kg} \\
\text { fertilizer mixture } \\
\text { APM and } 1 \mathrm{~kg} \\
\text { dolomite }^{\mathrm{c}}\end{array}$ & 58.1 & 11.5 & 125.9 & 69.9 & 19.0 \\
\hline
\end{tabular}

a Nutrient removal by nuts, fronds and residues of inflorescence of the coconut palms were calculated per hectare ( 158 palms) in a year (Average of three years removal data were used).

b Nutrient content of the soil was calculated by summing up the quantities of available nutrients in the manure circle and the rest of the area together up to a $1 \mathrm{~m}$ of depth taking the bulk density value of $1.6 \mathrm{~g} \mathrm{~cm}^{-3}$.

c Quantity of N, P, K \& Mg supplied by application of $3.3 \mathrm{~kg}$ APM fertilizer mixture and $1 \mathrm{~kg}$ dolomite per palm per year were converted to the $\mathrm{kg}$ of ha $\mathrm{yr}^{-1}$ (158 palms $\left.\mathrm{ha}^{-1}\right)$.

d Available $\mathrm{N} \mathrm{mg} \mathrm{kg}^{-1}$ in top $1 \mathrm{~m}$ layer in a hectare

Note : Available $\mathrm{N} \mathrm{mg} \mathrm{kg}^{-1}$ in top $1 \mathrm{~m}$ layer in a hectare of soil computed using total $\mathrm{N}\left(3726 \mathrm{mg} \mathrm{kg}^{-1}\right)$. It was assumed that $1-2 \%$ of the total $\mathrm{N}$ is in the available form (Brady, 1990). Computed available $\mathrm{N}$ in $1 \mathrm{~m}$ top layer of soil in hectare, using bulk density value of $1.6 \mathrm{~g} \mathrm{~cm}^{-3}$ in Boralu series soil.

e Available Olsen P content of top $1 \mathrm{~m}$ layer in a hectare

f Available exchangeable $\mathrm{K}, \mathrm{Ca}$ and $\mathrm{Mg}$ content of top $1 \mathrm{~m}$ layer in a hectare 
Nitrogen $\mathrm{P}, \mathrm{K}, \mathrm{Ca}$ and $\mathrm{Mg}$ removals by organic components of coconut palms were compared with reserves of available macronutrients in the soil upto $1 \mathrm{~m}$ depth at the experimental site and inputs of $\mathrm{N}, \mathrm{P}, \mathrm{K}, \mathrm{Ca}$ and $\mathrm{Mg}$ by standard coconut fertilizer application as given in Table 6 According to the Table 6, the N, P, Ca and Mg input by application of $3.3 \mathrm{~kg}$ of APM fertilizer mixture with $1 \mathrm{~kg}$ dolomite slightly exceeds the aforementioned nutrient depletion. In contrast, high yielding coconut plantations only $\mathrm{P}$ input by application of fertilizer exceeds the nutrient depletion (Somasiri et al. 2001 and 2003). It is assumed that 1-2\% of the total nitrogen in the soil is available in inorganic forms for plant uptake (Brady, 1990). Based on the above assumption, it can be considered that the total nitrogen quantity in the soil together with annual input by fertilizer is sufficient to compensate for the removal of $\mathrm{N}$ by palm for long run, if the present level of $\mathrm{N}$ in soil is maintained.

The soil reserves of available $\mathrm{P}$ would be sustained for a long period because of its low depletion rate and input by fertilizer slightly higher than the Premoval. Similar situation was observed in high yielding plantations (Somasiri et al. 2001 and 2003). The exchangeable pool of $\mathrm{Mg}$ would also be sustained for a long period due to its low depletion rate and input by fertilizer slightly higher than the $\mathrm{Mg}$ removal. The soil reserves of $\mathrm{Ca}$ would be also sustained for long period, due to the $\mathrm{Ca}$ input by both rock phosphate and dolomite exceeds the removal by the palm.

Hence, the $\mathrm{N}, \mathrm{P}, \mathrm{Ca}$ and $\mathrm{Mg}$ soil reserves of low yielding coconut plantations would not be rapidly depleted because the depletion is smaller than the input addition, eventhough harvested nuts and fallen plant components are removed from the plantations. However, it must be noted that depletion of sodium in the soil could result in due to removal by coconut palm in the absence of sodium fertilizer application. Application of mulch also would serve to replenish a mojor part of $\mathrm{Na}$ removed, since fallen fronds contained $62 \%$ of the total removal.

The $\mathrm{K}$ input (125.9 $\mathrm{kg} \mathrm{ha}^{-1} \mathrm{yr}^{-1}$ ) by the application of $3.3 \mathrm{~kg}$ of APM fertilizer mixture was about $76.7 \%$ of the $\mathrm{K}$ removal $\left(164.2 \mathrm{~kg} \mathrm{ha}^{-1}\right.$ $\left.\mathrm{yr}^{-1}\right)$. This leads to depletion of exchangeable soil $\mathrm{K}$ pool rapidly, if the harvested nuts and fallen plant components are all removed from the plantation. At a production rate of 7,500 nuts $\mathrm{ha}^{-1} \mathrm{yr}^{-1}$ despite the recommended fertilizer application the depletion rate of exchangeable $\mathrm{K}$ of the soil would be $38.3 \mathrm{~kg} \mathrm{ha}^{-1} \mathrm{yr}^{-1}$. Hence, the depletion should be compensated for either by increasing the quantity of chemical fertilizer or recycling organic components of the palm itself. However, the rapid $\mathrm{K}$ depletion take place even after application of $4.5 \mathrm{~kg}$ of APM fertilizer mixture in high yielding plantations (Somasiri et al. 2001 and 2003). Application of extra 80 $\mathrm{kg} \mathrm{ha}^{-1}$ of MOP would be sufficient to fill the gap between $\mathrm{K}$ removal and input by fertilizer. It is important to note that $\mathrm{K}$ input to soil at the recommended rate of both fertilizer and a mulch with all the fallen coconut fronds would be 156.7 $\mathrm{kg} \mathrm{ha}^{-1} \mathrm{yr}^{-1}$, which is still less than the rate of through uptake by the palm. The rate of depletion could be exceeded if fallen inflorescences are incorporated to the soil in addition to application of $3.3 \mathrm{~kg}$ of fertilizer and the mulch.

If all fallen fronds and infloresences applied as mulch to the manure circles and incorporated to the soil, the rate of depletion of $\mathrm{K}$ would be decreased considerably. Also, it would contribute to saving on inorganic $\mathrm{K}$ fertilizer required to compensate the depletion. The other practice could be mulched the manure circle with 
fresh husks (as soon as dehusking) in addition to application of the fertilizer. The $35 \%$ of the total $\mathrm{K}$ in husk is water soluble. Hence, $34.6 \mathrm{~kg}$ of water soluble fraction of $\mathrm{K}$ would be benefitted to compensate the $\mathrm{K}$ depletion. However, such practices are not adopted due to the industrial value of the husk. The rate of depletion can be exceeded if all the husks are incorporated to the soil in addition to application of fertilizer and mulch. Thus, the proper approach is to balance the plant nutrients in coconut plantations by incorporating organic compounds and residues of the palm itself to the soil and apply inorganic fertilizers only to make up for the differences between the input and the total removal. Rapid $\mathrm{K}$ depletion in high yielding plantations could be decreased by application of $4.5 \mathrm{~kg}$ APM mixture with recycling organic residues of the palm it self (Somasiri et al. 2003).

As seen from Table 7, the quantity of micronutrients in organic products of coconut palm was much smaller compared to that of macronutrients. With regard to the total removal of micronutrients, Fe was the highest. The other micronutrients removal in decending order was $\mathrm{Mn}, \mathrm{Zn}, \mathrm{B}$ and $\mathrm{Cu}$ respectively. Both the fronds and nuts removed relatively high amounts of Fe. The harvested nuts removed most of the $\mathrm{Cu}$, whereas fronds removed much of the $\mathrm{Mn}$. Nuts removed a higher quantity of $\mathrm{Zn}$ and $\mathrm{B}$ than other plant parts.

The soil reserves of available $\mathrm{P}$ would be sustained for a long period because of its low depletion rate and input by fertilizer slightly higher than the P removal. Similar situation was observed in high yielding plantations (Somasiri et al. 2001 and 2003). The exchangeable pool of $\mathrm{Mg}$ would also be sustained for a long period due to its low depletion rate and input by fertilizer slightly higher than the Mg removal. The soil reserves of $\mathrm{Ca}$ would be also sustained for long period, due to the $\mathrm{Ca}$ input by both rock phosphate and dolomite exceeds the removal by the palm.

Hence, the N, P, Ca and Mg soil reserves of low yielding coconut plantations would not be rapidly depleted because the depletion is smaller than the input addition, eventhough harvested nuts and fallen plant components are removed from the plantations. However, it must be noted that depletion of sodium in the soil could result in due to removal by coconut palm in the absence of sodium fertilizer application. Application of mulch also would serve to replenish a mojor part of $\mathrm{Na}$ removed, since fallen fronds contained $62 \%$ of the total removal.

The $\mathrm{K}$ input $\left(125.9 \mathrm{~kg} \mathrm{ha}^{-1} \mathrm{yr}^{-1}\right)$ by the application of $3.3 \mathrm{~kg}$ of APM fertilizer mixture was about $76.7 \%$ of the $\mathrm{K}$ removal $\left(164.2 \mathrm{~kg} \mathrm{ha}^{-1}\right.$ $\left.\mathrm{yr}^{-1}\right)$. This leads to depletion of exchangeable soil $\mathrm{K}$ pool rapidly, if the harvested nuts and fallen plant components are all removed from the plantation. At a production rate of 7,500 nuts $\mathrm{ha}^{-1} \mathrm{yr}^{-1}$ despite the recommended fertilizer application the depletion rate of exchangeable $\mathrm{K}$ of the soil would be $38.3 \mathrm{~kg} \mathrm{ha}^{-1} \mathrm{yr}^{-1}$. Hence, the depletion should be compensated for either by increasing the quantity of chemical fertilizer or recycling organic components of the palm itself. However, the rapid K depletion take place even after application of $4.5 \mathrm{~kg}$ of APM fertilizer mixture in high yielding plantations (Somasiri et al. 2001 and 2003). Application of extra 80 $\mathrm{kg} \mathrm{ha}^{-1}$ of MOP would be sufficient to fill the gap between $\mathrm{K}$ removal and input by fertilizer. It is important to note that $\mathrm{K}$ input to soil at the recommended rate of both fertilizer and a mulch with all the fallen coconut fronds would be 156.7 $\mathrm{kg} \mathrm{ha}^{-1} \mathrm{yr}^{-1}$, which is still less than the rate of through uptake by the palm. The rate of depletion 
could be exceeded if fallen inflorescences are incorporated to the soil in addition to application of $3.3 \mathrm{~kg}$ of fertilizer and the mulch.

If all fallen fronds and infloresences applied as mulch to the manure circles and incorporated to the soil, the rate of depletion of $\mathrm{K}$ would be decreased considerably. Also, it would contribute to saving on inorganic $\mathrm{K}$ fertilizer required to compensate the depletion. The other practice could be mulched the manure circle with fresh husks (as soon as dehusking) in addition to application of the fertilizer. The $35 \%$ of the total $\mathrm{K}$ in husk is water soluble. Hence, $34.6 \mathrm{~kg}$ of water soluble fraction of $\mathrm{K}$ would be benefitted to compensate the $\mathrm{K}$ depletion. However, such practices are not adopted due to the industrial value of the husk. The rate of depletion can be exceeded if all the husks are incorporated to the soil in addition to application of fertilizer and mulch. Thus, the proper approach is to balance the plant nutrients in coconut plantations by incorporating organic compounds and residues of the palm itself to the soil and apply inorganic fertilizers only to make up for the differences between the input and the total removal. Rapid $\mathrm{K}$ depletion in high yielding plantations could be decreased by application of $4.5 \mathrm{~kg}$ APM mixture with recycling organic residues of the palm it self (Somasiri et al. 2003).

As seen from Table 7 , the quantity of micronutrients in organic products of coconut Ipalm was much smaller compared to that of macronutrients. With regard to the total removal of micronutrients, Fe was the highest. The other micronutrients removal in decending order was $\mathrm{Mn}, \mathrm{Zn}, \mathrm{B}$ and $\mathrm{Cu}$ respectively. Both the fronds and nuts removed relatively high amounts of Fe. The harvested nuts removed most of the $\mathrm{Cu}$, whereas fronds removed much of the Mn. Nuts removed a higher quantity of $\mathrm{Zn}$ and B than other plant parts.

Table 7 : Total removal of micronutrients by nuts, fronds and inflorescence yielding 7,500 nuts ha-1 $\mathrm{yr}^{-1}$

\begin{tabular}{llllll}
\hline Parts of the palm & Fe & Mn & Cu & Zn & B \\
\hline Nuts & & \multicolumn{5}{c}{$\left(\mathrm{kg} \mathrm{ha}^{-1} \mathbf{y r}^{-1}\right)$} \\
Fronds & 0.39 & 0.12 & 0.06 & 0.12 & 0.08 \\
Inflorescence & 0.52 & 0.40 & 0.02 & 0.09 & 0.04 \\
\hline Total & 0.02 & 0.01 & 0.01 & 0.07 & 0.03 \\
\hline
\end{tabular}


The $\mathrm{Fe}, \mathrm{Mn}, \mathrm{Cu}$ and $\mathrm{Zn}$ removals by organic components of coconut palms were compared wtith reserves of available micronutrients in the soil upto the $1 \mathrm{~m}$ depth at the experimental site and input of $\mathrm{Fe}, \mathrm{Mn}, \mathrm{Cu}$ and $\mathrm{Zn}$ as impurities contain in APM fertilizer mixture (Table 8). As seen from the balance sheet of micronutrients (Table 8), the reserve of available $\mathrm{Fe}, \mathrm{Mn}, \mathrm{Cu}$ and $\mathrm{Zn}$ in Boralu series soil was very high compared to annual $\mathrm{Fe}, \mathrm{Mn}, \mathrm{Cu}$ and $\mathrm{Zn}$ removal by the palm. The gap between the soil reserves and the plant uptake rates of $\mathrm{Fe}, \mathrm{Mn}, \mathrm{Cu}$ and $\mathrm{Zn}$ were very high and therefore depletion of soil reserves would not occur rapidly. The ratio of removal to soil reserves for $\mathrm{Fe}, \mathrm{Mn}, \mathrm{Cu}$ and $\mathrm{Zn}$ were 563, 185,267 and 171 respectively. It implies that deficiency of Fe, $\mathrm{Mn}, \mathrm{Cu}$ and $\mathrm{Zn}$ would not occur for a longer period in Boralu series soil.

Table 8: Quantities of micronutrients (i) loss from the site via removal of plant components, (ii) As soil reserves in available form and (iii) Supplied by fertilizer inputs

\begin{tabular}{llllll}
\hline & Fe & Mn & Cu & Zn & B \\
\hline $\begin{array}{l}\text { (i) Nutrient removal by } \\
\text { nuts, fronds and } \\
\text { inflorescence of } \\
\text { coconut palms }\end{array}$ & 0.93 & 0.53 & 0.09 & 0.28 & 0.15 \\
& & & & \\
(ii) Soil nutrient content & 524 & 98 & 24 & 48 & ND \\
$\begin{array}{l}\text { (ii) Nutrient supplied by } \\
\text { application of 3.3 kg }\end{array}$ & 1.88 & 0.24 & 0.013 & 0.03 & ND \\
$\begin{array}{l}\text { APM and 1 kg } \\
\text { dolomite }\end{array}$ & & & & \\
\hline
\end{tabular}

a Nutrient removal by nuts, fronds and residues of inflorescences of the coconut palms were calculated per hectare (158 palms) in a year (Average of three years removal data were used).

b Nutrient status of the soil was calculated by summing up the quantity of available nutrients Nutrient removal through low yielding coconut plantations in the rest of the area.

c Quantity of nutrients supplied by application of $3.3 \mathrm{~kg} \mathrm{APM}$ and $1 \mathrm{~kg}$ dolomite $\mathrm{palm}^{-1} \mathrm{yr}^{-1}$ were converted to the rate of ha $\mathrm{yr}^{-1}\left(158\right.$ palms ha-1 $^{-1}$.

d Available micronutrients 
Other than fertilizer impurities, considerable amount of micronutrient removed by coconut palm could also te returned to the soil by using fronds, husks and inflorescence parts as mulch or manure. Therefore application of synthetic/ chemical fertilizer containing micronutrients would not be necessary Boralu series.

\section{CONCLUSIONS}

The decending order of macronutrient removal was $\mathrm{K}, \mathrm{N}, \mathrm{Na}, \mathrm{Ca}, \mathrm{Mg}$ and $\mathrm{P}$ respectively, in low potential coconut lands. Except $\mathrm{K}$, the other macronutrients, input by application of 3.3 $\mathrm{kg}$ APM with $1 \mathrm{~kg}$ dolomite slightly exceeds the nutrient removal. The $\mathrm{K}$ input by fertilizer was about $76.7 \%$ of the total $\mathrm{K}$ removal. This leads to depletion of exchangeable $\mathrm{K}$ pool rapidly, if the harvested nuts and fallen plant components are all removed from the plantations. Hence, the depletion should be compensated for either by adding extra $80 \mathrm{~kg} \mathrm{ha}^{-1}$ Muriate of Potash or recycling of fallen fronds and residues of the inflorescences or mulching the manure circle using fresh coconut husks.

The soil reserves of total $\mathrm{N}$, available $\mathrm{P}$, exchangeable $\mathrm{Ca}$ and $\mathrm{Mg}$ would be sufficient to surtain for a long period because of their low depletion rates and inputs by fertilizers slightly higher than the removals.

The Fe input by fertilizer residues exceeds the removal by palm and therefore reserves would be sufficient. However, the loss of Mn, $\mathrm{Cu}$ and $\mathrm{Zn}$ from the field is compensated by the input of fertilizer residue and the mulch. The reserve of available $\mathrm{Fe}, \mathrm{Mn}, \mathrm{Cu}$ and $\mathrm{Zn}$ in Boralu series soil was very high compared to removals by the palm and therefore application of fertilizer containing $\mathrm{Fe}, \mathrm{Mn}, \mathrm{Cu}$ and $\mathrm{Zn}$ would not be necessary.

\section{REFERENCES}

Brady N. C. (1990). The nature and properties of soils, $10^{\text {th }}$ Edition, John Wiley and Sons, Macmillan Publishing Company, New York.

Bremner J.M. and Mulvaney C.S. (1982) "Total nitrogen”, In: A.L. Page, R.H. Miller and D.R. Keeny, (Eds.), Methods of Soil Analysis, American Society of Agronomy and Soil Science Society of America, Madison, pp. 1119-1123.

Jeganathan M., Appuhamy P. A. G. A., Mendis B. J. A. F. and George G. D. (1977). Study on the annual exhaust of soil nutrients by the Typica $x$ Pumila hybrid palm, Proceedings of the Sri Lanka Association for the Advancement of Science, 32 (1) 43.

Jayasekara K. S., Jayasekara C. and Periyathambi S. (1991). Report of the Soils and Plant Nutrition Division, Annual Report of Coconut Research Institute, Lunuwila, Sri Lanka.

Kakulu S.E. and Jacob J.O. (2006). Comparison of digestion methods for Trace metal Determination in moss samples. Proceeding of the $1^{\text {st }}$ National Conference of the Faculty of Science, University of Abuja; p 77-81. 
Lindsay W. L. and Norvell W. A. (1978). Development of a DTPA Soil Test for Zinc, Iron, Manganese and Copper, Soil Scence Society of American Journal 42, 421 - 428.

Olsen S. R., Cole C. V., Watanabe F. S. and Dean L. A. (1954). Estimation of available phosphorus in soils by extraction with sodium bicarbonate In: Circular No: 939, Washington, D.C., United States Department of Agriculture, 1 -19.

Ohler J. G. (1984). Coconut tree of life, 446 p, Food and Agriculture Organization of the United Nations, Rome.

Ouvrier M., and Ochs R. (1980). Nutrient removal by hybrid coconut Port-Bouet 121 (MAWA). Proceedings of the International Conference on Cocoa and Coconut, Kuala Lumpur (Malaysia) 1978, 595-605.

Somasiri L. L. W., Wijebandara D. M. D. I., Sabarathnam S., Panditharathna B. D. P. and Perera U. S. S. (2000). Removal of plant nutrients of soils by nuts of coconut palms . Proceedings of the Sri Lanka Association for the Advancement of Science, 56 (1) 77.

Somasiri L. L. W., Wijebandara D. M. D. I., Panditharathna B. D. P., Sabarathnam S., Kurudukubura C. P. A., Pathirana K. P. A. (2001). Study on nutrient removal by Typica x Typica coconut palms in high potential lands. Proceedings of the Sri Lanka Association for the Advancement of Science, 57 (1) 40.

Somasiri L. L. W., Wijebandara D. M. D. I., Panditharathna B. D. P., Sabarathnam S. and Kurudukubura C. P. A. (2003). Loss of nutrients in a high yielding coconut plantation through removal of plant materials from the field. Cocos, 15: $12-22$.

Somasiri L. L. W., Nadarajah N., Amarasinghe L. and Gunathilake H. A. J. (1994). Land suitability assessment of coconut growing area in the coconut triangle. Occasional Publication Series No. 3, Coconut Research Institute, Lunuwila, Sri Lanka.

Thomas G. W. 1982. Exchangeable cations, In: Page, A. L., Miller, R. H. and Keeney, D. R., Methods of soil analysis, Part 2 - Chemical and Microbiological properties, Agronomy No. 9, Madison, Wisconsin, U.S.A. 159 - 164.

Kakulu S.E. and Jacob J.O., Comparison of digestion methods for trace metal determination in moss samples, Proceeding of the $1^{\text {st }}$ National Conference of the Faculty of Science, University of Abuja, (2006), 77-81. 